\title{
Teaching Adult Immigrants with Limited Formal Education: Theory, Research, and Practice. 2020. Edited by Peyton, Joy K. and Young-Scholten Martha. Bristol: Multilingual Matters, 208p; ISBN: 978-1-78309-996-2
}

\author{
Vanesa Alonso González
}

Citation: Alonso González, Vanesa. 2021. Teaching Adult Immigrants with Limited Formal Education:

Theory, Research, and Practice. 2020. Edited by Peyton, Joy K. and Young-Scholten Martha. Bristol: Multilingual Matters, 208p; ISBN: 978-1-78309-996-2. Languages 6: 11. https://doi.org/10.3390/

languages6010011

Received: 26 November 2020 Accepted: 30 December 2020 Published: 8 January 2021

Publisher's Note: MDPI stays neutral with regard to jurisdictional clai$\mathrm{ms}$ in published maps and institutional affiliations.

Copyright: (C) 2021 by the author. Licensee MDPI, Basel, Switzerland. This article is an open access article distributed under the terms and conditions of the Creative Commons Attribution (CC BY) license (https:// creativecommons.org/licenses/by/ $4.0 /)$.
Department of Modern Languages and Literatures, University of Ottawa, Ottawa, ON K1N 6N5, Canada; valonsog@uottawa.ca

\begin{abstract}
Teaching Adult Immigrants with Limited Formal Education: Theory, Research, and Practice is a compendium of the six modules that were the result of the third phase of the EU-Speak Project, European Speakers of Other Languages: Teaching Adult Migrants and Training Their Teachers, an ambitious collaborative research project carried out by several European and American universities with the purpose of orienting second language educators whose target pupils are immigrant second language learners with limited education and literacy. Each chapter covers different linguistic, psycholinguistic, sociolinguistic, and pedagogical issues in order to offer a complete guide to those interested in teaching a second language to this particular group of learners. As a result, the book presents itself as a link between researchers, teachers, policy-makers, and administrators with the common aim of integrating these learners as active members of their new countries through the acquisition of their new languages.
\end{abstract}

Keywords: adult immigrant; literacy; second language learning; EU-Speak

Even though they have received little attention within academia, adult immigrant second language learners with limited education and literacy are the main characters of many headlines in the mass media. Twelve years ago, several European universities purposefully moved towards helping immigrant adults to become literate in the languages of their new countries. With this aim, from 2010 to 2018, the EU-Speak project was carried out in three phases, with new universities from Europe and the United States joining in. A portrait of the third phase of this project is presented in this book.

The book presents itself as a link between researchers, teachers, policy-makers, and administrators. It comprises seven chapters and, with the exception of the first one, every chapter encompasses each of the six educational modules that were created within the third phase of the EU-Speak project European Speakers of Other Languages: Teaching Adult Migrants and Training Their Teachers (i.e., Language and Literacy in Social Context; Reading from a Psycholinguistic perspective; Vocabulary; Acquisition and Assessment of Morphosyntax; Bilingualism and Multilingualism, and; Teaching and Tutoring Adult Learners with Limited Education and Literacy). These modules were the result of international surveys administered among teachers that helped to develop a curriculum devoted to providing enough knowledge and skills to educators and tutors who look after this particular population. The didactic tone of this book, kept along with the chapters despite its different authors, facilitates its reading and makes it a useful reference in the field of second language teaching.

The editors, Young-Scholten and Kreeft Peyton, are the authors of the first chapter, a chapter that explains the need for such a project to become real. This first chapter serves as an introductory set for the rest of the book. It takes a sociolinguistic perspective that 
helps the reader to understand the particular context of these learners, as well as the many challenges they encounter on their way to become literate in a second language as adults.

Chapter 2 consists of a reflection on the idea of literacy, understood by the Western countries as a universal domain and as a universal right. Something that, according to the authors, Suni and Tammelin-Laine, may not be shared by some of the countries of origin of this specific immigrant population, which entails a double challenge, i.e., learn how to write and read for the first time in a language that differs, sometimes greatly, from their native language. This approach provides a useful context to those who want to teach this particular group because it helps to understand their students and, therefore, to empathize with them, too. Using examples from European countries such as Sweden and the United Kingdom, but especially from Finland, the chapter presents different scenarios where literacy is most needed, among them work and parenting. The authors specifically focus on the idea that language instruction should be linked to daily life and the current needs of this particular group of learners. Another important consideration of this chapter is the idea of multiliteracies and new literacies, a new reality that not only immigrant adults have to deal with, but the entire educational system. In particular, this chapter presents the Finnish Core Curriculum for Basic Education where a clear openness to every kind of communication is briefly treated, comprising not just spoken or written modes. In fact, a common denominator of this book, starting in this chapter, is the idea of presenting different examples from specific countries and the instructional and administrative practices that have been implemented in these places. This can be considered as highly illustrative, even as a model to follow. Yet, to replicate these models in other countries with other socioeconomic priorities and GDP (Gross Domestic Product) could prove a demanding task.

Another common element throughout the book is that it refers to studies that have been carried out among young children, studies whose conclusions are extrapolated to adult second language learners with no literacy skills who are considered to be (with nuances) at a similar starting point as children. An example of this is the idea that both of these groups "pass through the same phases in the process of developing word recognition" (Kuvers 2007). This continuous extrapolation is due to the scarcely available literature on adult immigrants with little or no literacy skills, an issue that this book tries to address from different points of view. An example of this aim can be seen in Chapter 3, devoted to the development of reading skills. This chapter, written by Sosiński, decomposes the process of reading and presents two optimistic insights regarding adult literacy. One is related to the nonexistence of a critical period when learning to read (Young-Scholten and Strom 2006); the second, and more specific one, is related to phonemic awareness in an alphabetic script, a skill that is not constrained by age either. This chapter also reveals what lies behind the process of reading, describing bottom-up and top-down processing strategies as well as the implications of confronting these adults to writing systems that may differ from their own. Then, the chapter adopts an empirical viewpoint when presenting different approaches to reading, from the classic synthetic and analytical approach to other alternatives that include the generative method and the language experience approach. Thus, it offers a wide spectrum of possibilities that gives instructors plenty of options to implement in the classroom. Finally, the chapter focuses on extensive reading and its counterpart, reading for pleasure, a goal that may seem naïve when confronted with the imminent necessities of practical reading, yet a task that can be posed as a medium or long-term goal. This last issue also pinpoints the necessity of increasing the quality and quantity of accessible reading materials oriented to these learners.

Chapter 4 concentrates on the acquisition of vocabulary. The joint work by Rohde, Chlubek, Holtappels, Schick, and Schnuch begins by exploring what can be found underneath the knowledge of a word and the nature of the mental lexicon itself, understood as a net whose different connections have to be instilled not only inside but also outside the classroom. Regarding the ways of learning vocabulary, the authors describe various strategies behind implicit and explicit learning that, according to Haudeck (2008), can be 
complementary. When describing these strategies, it is noted that some migrant adults with little or no formal education could require extra support from the instructor who may need to introduce explicitly these learning strategies before confronting new vocabulary; something that may pose an extra challenge for both teacher and learner, especially if the teacher does not know the learner's first language. Special mention is given to fast mapping: the innate ability to connect meaning quickly with its linguistic forms, i.e., words, a process that remains accessible across a life span, according to the authors. Previous knowledge, frequency of appearance, the category of the word, and the physical environment are some of the issues that have to be taken into consideration when learning a new word effectively. Once the human skill of learning, retaining, and accessing new words is discussed, the chapter addresses the issue of deciphering its significance. The chapter ends with a practical and didactic approach on how to teach vocabulary to these particular learners and, among the different methods presented, the chapter describes semantic mapping, Venn diagrams, four squares, and derivational morphology.

In Chapter 5, Young-Scholten and Naeb discuss the acquisition and assessment of morphosyntax. In order to describe adult learners' initial state when facing a second language, the authors begin by describing different theories of first and second language acquisition with a special focus on morphosyntax. The concept of interlanguage (Selinker 1972), which the text defines as the "evolving system that the learner subconsciously creates in his or her mind", stands out as a key element when defining the starting point of learning a second language, specifically the issue of how L2 learners of any age systematize the acquisition of morphosyntax in a similar way as L1 children do (Schwartz and Sprouse 2013). It also addresses the current debate about the existence of a critical period on L2 acquisition and how some responses can be found in the field of neurolinguistic research. Interesting enough is the idea brought up by Hawkins (2001) that "there are common stages of development that are largely independent of the learner's L1; the learner's age at initial exposure to the L2; the type of exposure (naturalistic versus classroom); and the learner's educational background." After presenting different stages in the acquisition process of L2 morphosyntax, the chapter approaches the analysis of those factors stated by Hawkins and their influence on L2 acquisition. Regarding the L1, they refer to the full transfer/full access hypothesis (Schwartz and Sprouse 1996) with special mention to functional categories which, according to Hawkins (1997) and Hawkins and Liszka (2003), are impossible to learn if they are not shared between the L1 and the L2. With respect to the educational background, some authors view literacy as a factor that does alter the acquisition of morphosyntax (Tarone and Bigelow 2005). In relation to the type of exposure, the chapter focuses on the usefulness of memorizing multi-word expressions and also theorizes about instruction through rules, where the difference between the "simplicity" of a linguistic phenomenon and the "ease" of learning or acquiring it is mentioned. Finally, the chapter concludes with some reflections about assessing the learner's progress, which leads to the idea of accepting other possibilities apart from the use of standardized tests that may not be adequate enough to measure migrant adults' language proficiency.

In Chapter 6, Haznedar presents a snapshot of the main aspects related to bilingualism considered as a "widespread phenomenon". Starting with different types of bilinguals and bilingual situations, where, among other topics, code-switching is mentioned, the text moves into a deeper observation on bilingual acquisition compared to monolingual acquisition. Here, the author exposes the Unitary Language Systems Hypothesis (Volterra and Taeschner 1978) versus the Independent Development Hypothesis (Lindholm and Padilla 1978). The former argues for the existence of a single initial system in simultaneous bilinguals, while the latter argues for the existence of two separate linguistic systems from the earliest stages of acquisition. When comparing monolingual with bilingual stages of acquisitions, the author highlights some differences in vocabulary and morphosyntax. He also states how cross-linguistic influence is bound to occur between both languages (Serratrice et al. 2004), especially in the case of sequential bilinguals, those individuals whose second language is acquired after the core aspects of the L1 have been established 
(Haznedar 2010). This may result in incorrect utterances that are "highly systematic" nonetheless. These differences between monolingual and bilingual acquisition and even between different types of bilinguals may be considered as a disadvantage of bilingualism. The reality, however, is quite different, according to the author, because "knowing more than one language seems to confer cognitive advantages", for example, with respect to those tasks related to the executive functioning system (Miyake and Friedman 2012), among them the processes of verbal and nonverbal executive control (Bialystok et al. 2009). The chapter finishes with a special mention of biliteracy in children and how to deal with it when the mother tongue is a minority language in the society of the individual. This leads us to the reality of heritage speakers, "bilinguals exposed to a language that is ethnolinguistically different from the majority language spoken by the majority of the population in that society (Montrul 2010). In fact, according to Montrul (2008), "as a result of receiving early input in the L2, the minority language can lag behind and develop incompletely". For this reason, this chapter encourages the maintenance of immigrants' home languages which can result in balanced bilingualism and biliteracy-something that, in Haznedar's words, "has been actively discouraged in some contexts". This leaves open the debate on how to implement effective educational policies that allow us to keep minority languages within future generations.

The last chapter could be considered the framework for a teacher to position himself or herself when teaching and tutoring migrant adults with limited education. According to the authors, Faux and Watson, knowing the background of the students is key to academic progress. This background covers a series of elements, from their literacy background to their personal circumstances, including their cultural and religious context. All this will provide an engaging learning environment with the ultimate goal of creating "independent learners". This may pose a great challenge to the teacher who may have to confront fundamental differences between their students. This chapter also incorporates strategies that can help teachers to address issues such as lesson planning, selection of teaching materials, or assessment.

In conclusion, this is a ground-breaking volume that, albeit mostly oriented to teachers, can also be enlightening to policy-makers, researchers, and administrators, because it portrays an unknown reality as well as a growing necessity, i.e., helping immigrant adults to become literate in a second language. It also opens new doors to confront the need for conducting more research in this field, because most of the conclusions reached in this book are based on research carried out with children, yet immigrant adults have their own unique characteristics that make them a subject of interest for specialized investigation.

Funding: This research received no external funding.

Institutional Review Board Statement: Not applicable.

Informed Consent Statement: Not applicable.

Data Availability Statement: Data sharing not applicable.

Conflicts of Interest: The author declares no conflict of interest.

\section{References}

Bialystok, Ellen, Fergus Craik, David Green, and Tamar Gollan. 2009. Bilingual minds. Psychological Science in the Public Interest 10: 89-129. [CrossRef] [PubMed]

Haudeck, Helga. 2008. Fremdsprachliche Wortschatzarbeit Außerhalb des Klassenzimmers. Eine Qualitative Studie zu Lernstrategien und Lerntechniken in den Klassenstufen 5 und 8. Tübingen: Gunter Narr.

Hawkins, Roger. 1997. The partial availability of Universal Grammar in second language acquisition: The "Failed Functional Features Hypothesis". Second Language Research 13: 187-226. [CrossRef]

Hawkins, Roger. 2001. Second Language Syntax. A Generative Introduction. Malden: Blackwell.

Hawkins, Roger, and Sarah Liszka. 2003. Locating the source of defective past tense marking in advanced L2 English speakers. In The Lexicon-Syntax Interface in Second Language Acquisition. Edited by Roeland van Hout, Aafke Hulk, Folkert Kuiken and Richard Towell. Amsterdam: John Benjamins, pp. 21-44. 
Haznedar, Belma. 2010. Transfer at the syntax-pragmatics interface: Pronominal subjects in bilingual Turkish. Second Language Research 26: 355-78. [CrossRef]

Kuvers, Jeanne. 2007. Emerging literacy in adult second-language learners. A Synthesis of research findings in the Netherlands. Writing Systems Research 7: 58-78. [CrossRef]

Lindholm, Kathryn, and Amado Padilla. 1978. Language mixing in bilingual children. Journal of Child Language 5: 327-35. [CrossRef] Miyake, Akira, and Naomi Friedman. 2012. The nature and organization of individual differences in Executive Functions: Four general conclusions. Current Directions in Psychological Science 21: 8-14. [CrossRef] [PubMed]

Montrul, Silvina. 2008. Incomplete Acquisition in Bilingualism: Re-Examining the Age Factor. Amsterdam: John Benjamins.

Montrul, Silvina. 2010. Current issues in heritage language acquisition. Annual Review of Applied Linguistics 30: 3-23. [CrossRef]

Schwartz, Bonnie, and Rex Sprouse. 1996. L2 cognitive states and the Full Transfer/Full Access model. Second Language Research 12: 40-72. [CrossRef]

Schwartz, Bonnie, and Rex Sprouse. 2013. Generative approaches and the poverty of the stimulus. In Cambridge Handbook of Second Language Acquisition. Edited by Julia Herschensohn and Martha Young-Scholten. Cambridge: Cambridge University Press.

Selinker, Larry. 1972. Interlanguage. International Review of Applied Linguistics in Language Teaching 10: 209-31. [CrossRef]

Serratrice, Ludovica, Antonella Sorace, and Sandra Paoli. 2004. Crosslinguistic influence at the syntax-pragmatic interface: Subjects and objects in English-Italian bilingual and monolingual acquisition. Bilingualism: Language and Cognition 7: 183-205. [CrossRef]

Tarone, Elaine, and Martha Bigelow. 2005. Impact of literacy on oral language processing: Implications for SLA research. Annual Review of Applied Linguistics 25: 77-97. [CrossRef]

Volterra, Virginia, and Traute Taeschner. 1978. The acquisition and development of language by bilingual children. Journal of Child Language 5: 311-26. [CrossRef]

Young-Scholten, Martha, and Nancy Strom. 2006. First-time L2 readers: Is there a critical period? In Low-educated Second Language and Literacy Acquisition: Proceedings of the Inaugural Symposium. Edited by Ineke van de Craats, Jeanne Kurvers and Martha Young-Scholten. Utrecht: Landelijki Onderzoekschool Taalwetenschap (LOT), pp. 45-68. 